\title{
WELFARE LEVELS IN HERITAGE BREED VS. COMMERCIAL LAYING HENS IN THE LITTER SYSTEM*
}

\author{
Ewa Sosnówka-Czajka, Eugeniusz Herbut, Iwona Skomorucha, \\ Renata Muchacka
}

Department of Technology, Ecology and Economics of Animal Production, National Research Institute of Animal Production, 32-083 Balice n. Kraków, Poland

\begin{abstract}
The objective of the study was to determine differences in welfare levels between heritage breed hens (Yellowleg Partridge, Sussex, Leghorn) and commercial crosses (ISA Brown, Lohmann Brown, Hy-Line) kept in the litter system with no outdoor access. The experiment was carried out with 180 hens of three heritage breeds (Yellowleg Partridge, Sussex, Leghorn) and 180 commercial crosses of laying hens (Hy-Line, ISA Brown, Lohmann). Layers were reared in the litter system with no outdoor access. During the experiment, production data were collected until 38 days of age and birds' behaviour was monitored for $24 \mathrm{~h}$ at 18, 20, 32 and 38 weeks of age. Of the three commercial lines of laying hens kept in the litter system with no outdoor access, the lowest welfare levels were characteristic of ISA Brown birds. Hy-Line and Lohmann layers were characterized by comparable welfare levels that were higher in relation to ISA Brown layers. The results also showed that Sussex hens reared in the litter system had higher welfare levels than Yellowleg Partridge and Leghorn hens. When comparing the results of heritage breed and commercial hens, it can be said that mortality and increased levels of aggression in heritage breed hens kept in the litter system suggest that their welfare levels were lower than in commercial layers.
\end{abstract}

Key words: laying hens, welfare, behaviour, production results

The behaviour of birds is determined by their genetic origin. Väisänen et al. (2005) hold that modern breeding lines of chickens have poorer social learning capacity and show a weaker ability to cope with group disruptions compared to the ancestral breed. Meanwhile, Anderson et al. (2007) believe that long-term genetic selection in layer flocks to enhance production parameters has no impact on behaviour patterns in the next production cycles.

Many studies have also demonstrated differences in the behaviour of poultry of the same species that originate from different commercial lines (Anderson et al.,

*This study was financed from statutory activity, project no. 4141. 
2004; Fraisse and Cockrem, 2006). Based on behavioural observations of various local lines of poultry, Lee and Chen (2007) suggest that each of them has different requirements and should be kept in different systems to ensure proper welfare. According to Lay et al. (2011), no single housing system is ideal from a hen welfare perspective, each has its merits and shortcomings, and not every breed and commercial line is suited for every system. The choice of the production system, breed or commercial line of laying hens must be well considered to minimize the risks and ensure high productivity while maintaining proper welfare levels.

The objective of the study was to determine differences in welfare levels between heritage breed hens (Yellowleg Partridge, Sussex, Leghorn) and commercial crosses (ISA Brown, Lohmann Brown, Hy-Line) kept in the litter system with no outdoor access. Production results and bird behaviour were analysed.

\section{Material and methods}

The experiment was carried out with 180 hens of three heritage breeds (Yellowleg Partridge, Sussex, Leghorn) and 180 commercial crosses of laying hens (HyLine, ISA Brown, Lohmann). Layers were reared in the litter system at a stocking density of $9 \mathrm{birds} / \mathrm{m}^{2}$ and had no outdoor access. Birds were assigned to groups I to VI (Yellowleg Partridge, Sussex, Leghorn, and commercial layers Hy-Line, ISA Brown and Lohmann, respectively). Each group was subdivided into 3 subgroups, each having 20 birds. Birds were fed ad libitum standard diets based on concentrates for laying hens. Birds had free access to water throughout the experiment. All the groups were managed under uniform environmental (air humidity and temperature, lighting programme) and feeding conditions.

During the experiment, production data were collected on egg production, mortality, feed consumption per bird, and feed consumption per kg of eggs. At 18, 20, 32 and 38 weeks of age, the behaviour of hens was video recorded for $24 \mathrm{~h}$. The behavioural observations focused on the number of drinking, eating, resting, standing/walking, preening, aggressive, pecking, and ground scratching birds.

The results were analysed statistically using Statistica ver. 6. Significant differences between the experimental groups were verified by analysis of variance and Duncan's multiple range test for production traits, and by the chi-square test for behavioural observations.

\section{Results}

Table 1 presents the production results of the hens. Within heritage breeds, the highest laying percentage and the best feed conversion were found in group I in Yellowleg Partridge hens. Among the commercial lines, the best egg production was found in Hy-Line layers and the most efficient feed conversion in Lohmann hens. The survival rate was $100 \%$ for all three commercial lines and for Sussex layers. 


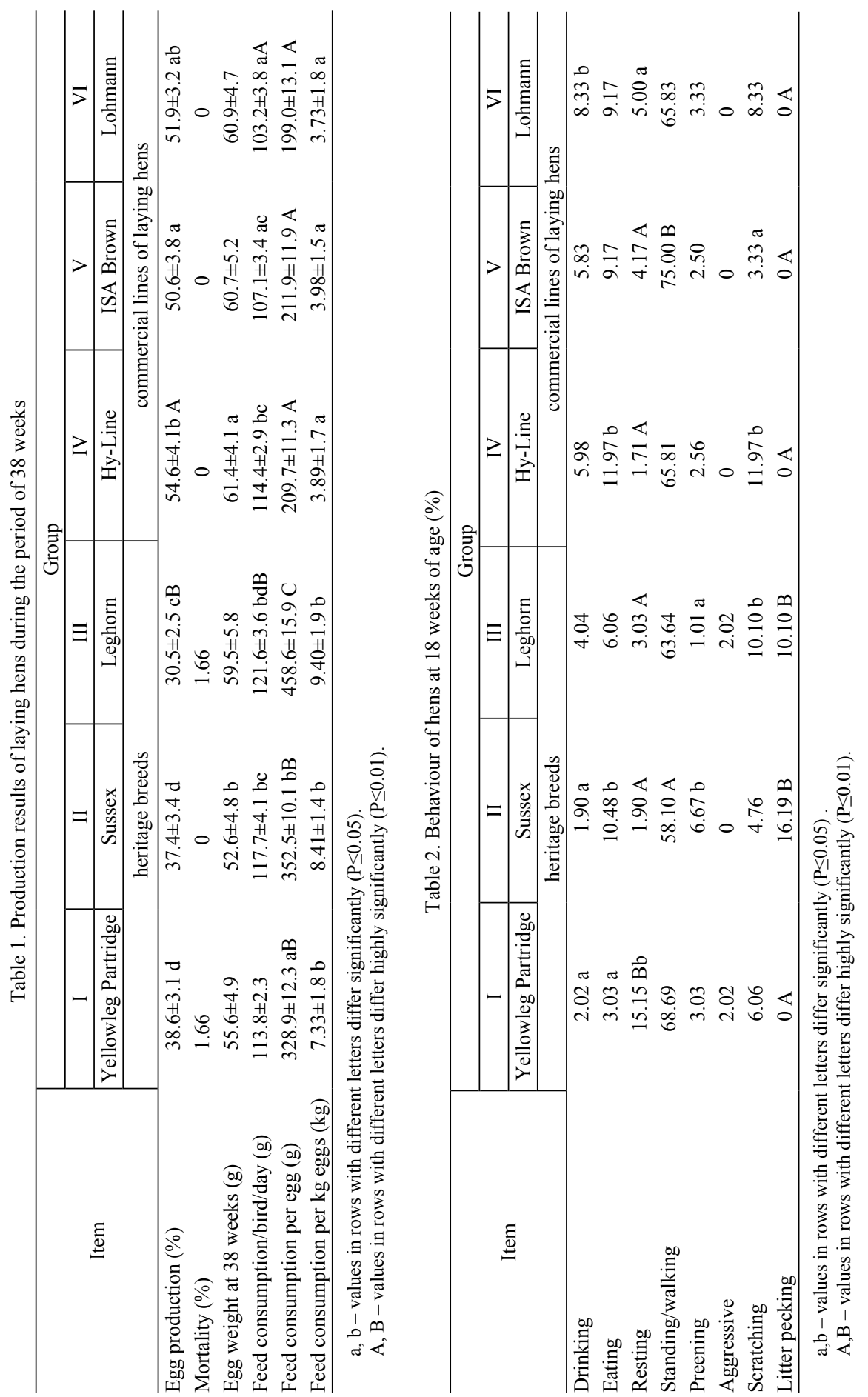




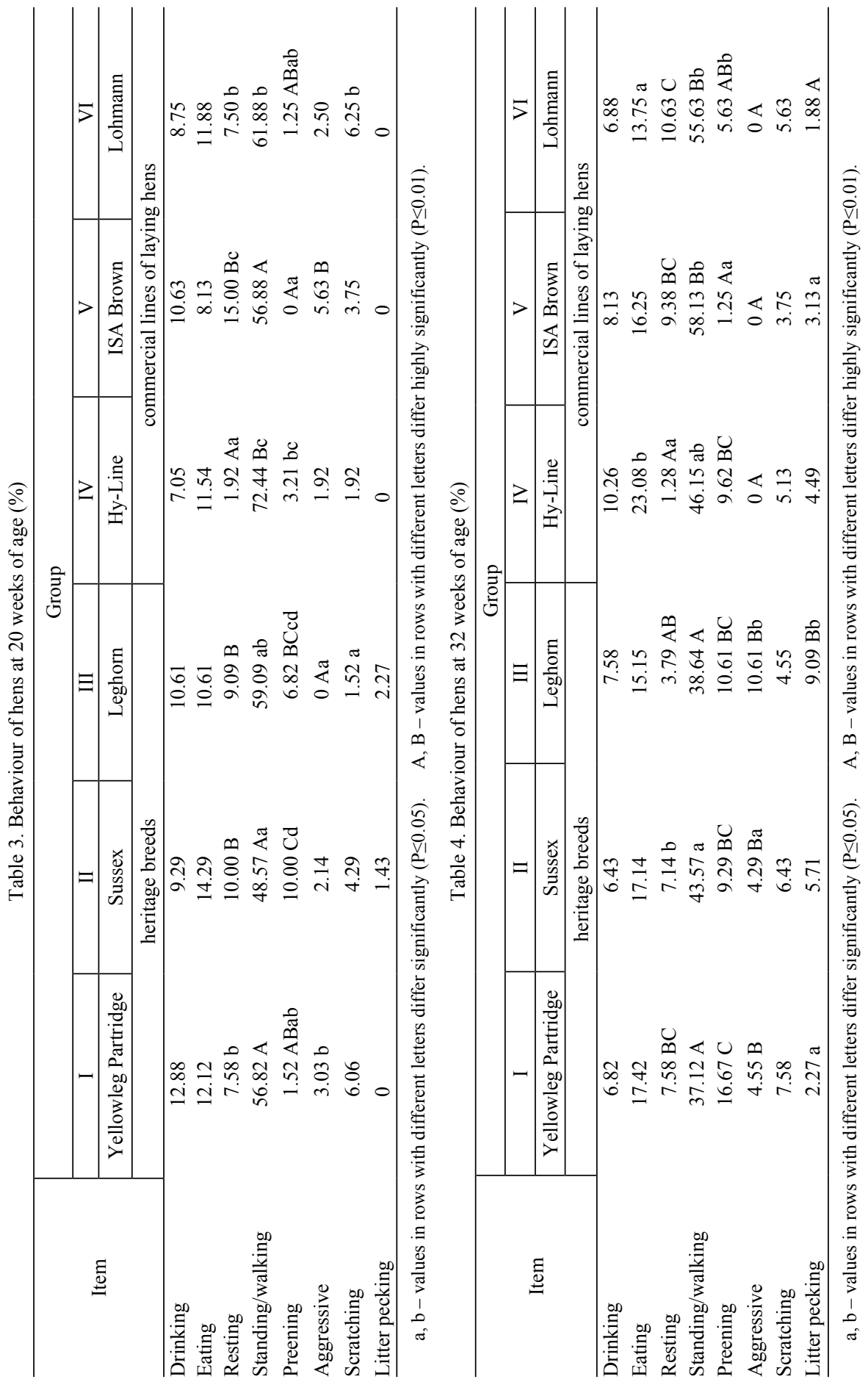




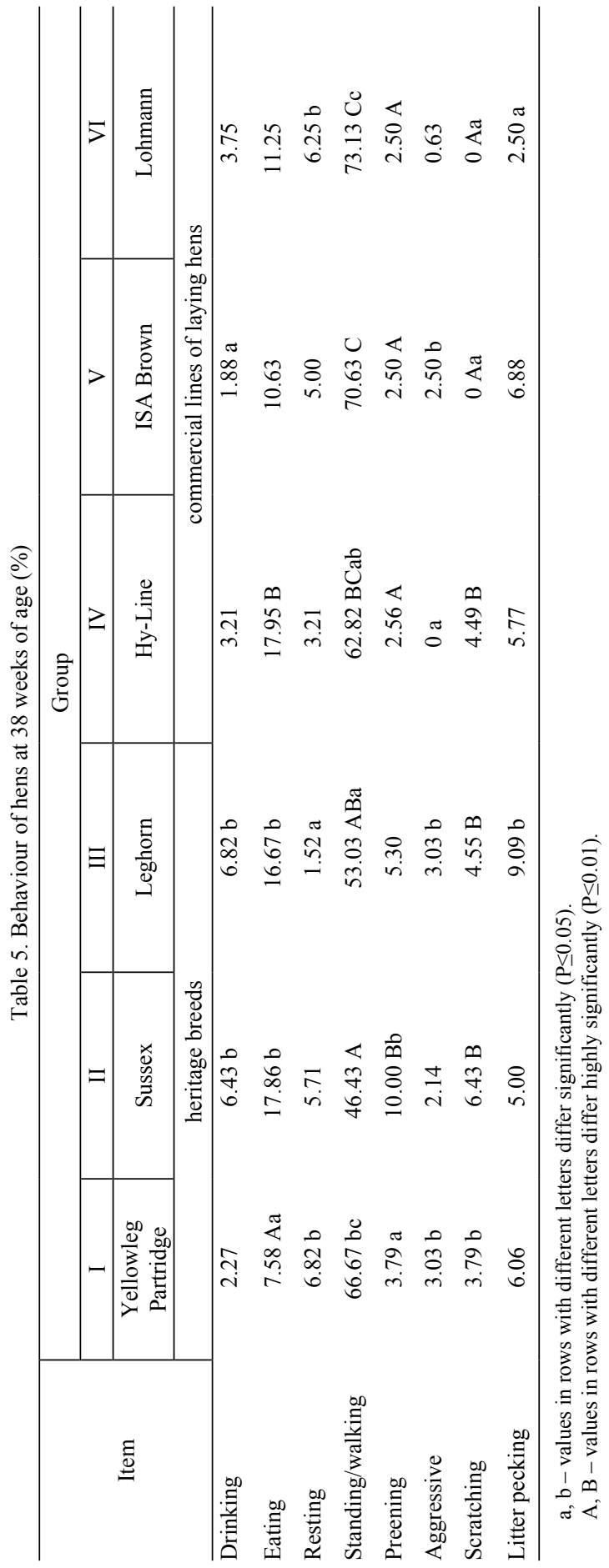


Tables 2-5 show the behaviour of hens at different weeks of age. No aggression was observed in the commercial lines of hens and in Sussex layers at 18 weeks of age (Table 2). Yellowleg Partridge layers rested most frequently and Hy-Line hens least frequently $(\mathrm{P} \leq 0.01)$.

The greatest behavioural differences were noted at 20 weeks of age for resting, standing and preening birds (Table 3). Laying hens of the Hy-Line strain were characterized by the lowest percentage of resting birds and the highest percentage of standing/walking birds. Sussex hens were characterized by the greatest number of preening birds and no such behaviour was observed in ISA Brown commercial layers $(\mathrm{P} \leq 0.01)$. There were no statistically significant differences between the groups in the number of drinking, eating and litter pecking birds.

The behavioural observations made at 32 weeks of age showed no aggressive behaviour among the commercial lines $(\mathrm{P} \leq 0.01)$ (Table 4). Hy-Line hens were characterized by the significantly lowest number of resting birds, and the highest percentage of resting layers was found for Lohmann hens $(\mathrm{P} \leq 0.01)$. No significant differences were found in the percentage of drinking and litter scratching birds among the experimental groups.

Table 5 presents the behaviour of hens at 38 weeks of age. The number of preening and scratching birds was significantly the highest in the Sussex group compared to the other groups, and the lowest in ISA Brown layers.

\section{Discussion}

In the European Union, eggs are currently produced in the intensive system, mainly in cages, but also on litter or with outdoor access (Tauson, 2002). Each of the current methods of layer housing and technological solutions has some problems such as social stress, unfavourable thermal and humidity conditions, or the inability to show the natural patterns of behaviour that determine avian productivity and welfare.

Productivity is considerably influenced by genetic selection in laying hens (Silversides et al., 2006) and by genetic properties of a given population in laying hens from conservation flocks (Calik, 2009). When comparing 3 commercial lines of laying hens, Silversides et al. (2006) found that Brown Leghorn (BL) differed in egg production compared to Babcock B-300 (BAB) and ISA Brown hens (ISAB). BL hens were characterized by lower feed consumption and required more feed to produce a dozen eggs. The same authors observed no statistically significant effect of origin on egg weight. However, Singh et al. (2009) showed a difference in the weight of eggs from hens of different commercial lines kept on litter. Our study revealed no differences in the weight of eggs from layers of different commercial lines. Likewise, Scott and Silversides (2000) did not find any differences in egg weight between ISA Brown and ISA White hens.

Singh et al. (2009), who compared production results in different commercial strains of laying hens kept in cages and floor pens, found that Lohmann White, 
H\&N White, Lohmann Brown and a non-commercial cross between Rhode Island Red (RIR) and Barred Plymouth Rock (BPR) were characterized by widely different production results in floor pens. Daily feed consumption was the highest in $\mathrm{RIR} \times \mathrm{BPR}$ layers and the lowest in H\&N White layers, with no differences between Lohmann White and Brown. A similar situation occurred for feed consumption per egg. The lowest feed consumption was found in H\&N White and the highest in RIR $\times$ BPR birds. There were no differences in feed consumption per egg between Lohmann White and Lohmann Brown hens. In our study, daily feed consumption per bird was the lowest in Lohmann layers and the highest in Hy-Line hens.

Singh et al. (2009) also revealed that origin has an effect on egg production in chickens of different commercial lines. The highest egg production was obtained by Lohmann White and Lohmann Brown, and the lowest by H\&N White birds. In our study, ISA Brown hens were characterized by the lowest egg production and feed conversion per egg and per kg of eggs of all three commercial lines. Hens of the Lohmann commercial line were characterized by the best feed conversion compared to hens of the other commercial lines, whereas Hy-Line hens had the highest egg production compared to ISA Brown and Lohmann hens.

In the case of heritage breed hens (groups I-III) reared without outdoor access, production results were best in Yellowleg Partridge and poorest in Leghorn hens. The weight of eggs from heritage breed hens showed differences, which is consistent with the findings of Calik (2009).

When raising laying hens of different commercial lines, Singh et al. (2009) found that origin had a significant effect on mortality. In our study, however, mortality occurred only for heritage breed hens. Yellowleg Partridge and Leghorn layers had a mortality of $1.66 \%$, whereas no mortality occurred in Sussex hens.

Genetic origin is a significant factor affecting avian behaviour (Nielsen et al., 2003; Cheng and Muir, 2004; Lay et al., 2011). According to Wirén et al. (2009), domestication of poultry and breeding work aimed at improving production parameters resulted in high genetic variation, which had a direct effect on differences in the behavioural patterns of individual poultry lines. Mahboub et al. (2004) showed differences in the behaviour of birds representing two different commercial lines. Lohmann Selected Leghorn (LSL) layers were characterized by greater activity compared to layers of the Lohmann Traditional commercial line. Also Klein et al. (2000), who investigated the behaviour of birds representing two commercial lines of laying hens: LSL and Dekalb, found that genetic origin had an effect on the behaviour of poultry. LSL birds spent more time foraging and less time resting compared to Dekalb birds. In our study, a difference in feed intake by layers of commercial lines was only observed at 32 weeks of rearing. Hens of the Hy-Line commercial line spent $9.33 \%$ more time feeding than Lohmann layers. However, throughout the experiment, there was only a tendency for about $5 \%$ more frequent feed consumption in Hy-Line birds compared to the other two commercial lines of laying hens. We observed a similar relationship to that reported by Klein et al. (2000), who showed that the birds that ingested food most often spent least time resting. Throughout the rearing period, Hy-Line hens exhibited a tendency for less frequent and shorter rest- 
ing by about $6 \%$ compared to ISA Brown and Lohmann birds. However, this difference was significant only at 20 and 32 weeks of growth.

Hens of the commercial lines were characterized by a relatively low level of aggression, with no aggressive behaviours observed at 18 and 32 weeks, and sporadic aggression found in the other weeks. During the experiment, ISA Brown birds tended to be $1.4 \%$ more aggressive compared to the other two commercial lines of laying hens. The behaviours indicative of proper welfare, such as preening, scratching and litter pecking were most frequent in Hy-Line and Lohmann birds. In ISA Brown layers, this frequency was about $6 \%$ lower than in hens from groups IV and VI.

Hocking et al. (2001), who compared the behaviour of Tetra and ISA Brown layers, found that origin had no effect on the frequency of litter pecking but showed a difference in preening frequency in favour of Tetra layers. Similar results were obtained in our study. We observed no differences between commercial lines in the proportion of litter pecking birds, whereas Hy-Line layers preened their feathers more frequently than ISA Brown birds.

Also in the case of heritage breed hens, the origin determines the behaviour of birds, which is confirmed by the studies of Uitdehaag et al. (2008, 2009) concerning the behaviour of Rhode Island Red and Leghorn layers. In our study, Yellowleg Partridge hens ingested feed least frequently at 18 and 38 weeks of rearing, with a tendency throughout the experiment for the least frequent visits to the feeder in these birds compared to the other two heritage breeds. Like for commercial layers, less frequent feed consumption was paralleled by longer resting time in Yellowleg Partridge birds. Sussex hens tended to show the lowest aggression within the heritage breeds studied. The behaviours indicative of high welfare, i.e preening, scratching and litter pecking were most prevalent in Sussex layers, in which they were as much as about 7\% more frequent than in Yellowleg Partridge birds.

Litter management is one of the best systems in terms of avian behaviour, where large space allowance compared to the cage systems allows birds to perform their full range of moving behaviour (Lay et al., 2011). In addition, the presence of litter stimulates the birds' natural behaviours associated with environmental exploration and foraging, i.e. walking, scratching and litter pecking (Aerni et al., 2000; Nicol et al., 2001). It should be noted that the type of bedding material as well as its quality and quantity are the crucial factor affecting this type of behaviour (Hetland and Svihus, 2007; Lay et al., 2011). In our study, the natural patterns of behaviour, i.e. preening, pecking and litter scratching were manifested more than twice as often in heritage breed hens than in hens of the commercial lines.

According to El-lethey et al. (2001), stress has an effect on the behaviour of birds. Heritage breed hens, which represent primitive breeds, are best suited to outdoor access systems, whereas confined housing increases stress symptoms, which in our study was reflected in behavioural changes and increased aggression compared to the commercial layers, which are able to tolerate litter management without outdoor access. Our results support the findings of Wirén et al. (2009), who believe that the domestication of poultry and intensive selection to improve production parameters helped to reduce the level of aggressiveness in high-producing birds compared to heritage breeds. Similar results were obtained in the present study, in which heritage 
breed hens raised without outdoor access were characterized by relatively high levels of aggression, which was an average of $2 \%$ higher than in commercial layers.

According to Nielsen et al. (2003), heritage breed hens are characterized by much greater locomotor activity compared to commercial poultry, which spends more time lying down and feeding. However, our study failed to show this relationship. When analysing the proportion of resting and walking layers, we generally found no differences between heritage breed and commercial hens.

In summary, ISA Brown hens showed the highest aggression and the lowest percentage of behaviours indicative of good welfare compared to layers of the other two commercial lines. As a consequence, ISA Brown hens also achieved the poorest production results of all the commercial lines studied. Thus, the results of behavioural observations and the production results indicate that of the three commercial lines of laying hens raised on litter without outdoor access, the lowest welfare was characteristic of ISA Brown birds. Hy-Line and Lohmann birds were characterized by comparable welfare levels that were higher than in ISA Brown layers.

Our results also demonstrate that Sussex hens reared in the litter system with no outdoor access had higher welfare levels than Yellowleg Partridge and Leghorn hens, as evidenced by no mortality and the relatively low level of aggression, paralleled by a high proportion of behaviours found in the natural behavioural pattern of the hens (preening, scratching and litter pecking).

When comparing the productivity of heritage breed and commercial hens, it can be said that mortality results and increased levels of aggression in heritage breed hens kept in the litter system suggest that their welfare levels were lower than in commercial layers.

\section{References}

A erni V., El-Lethey H., We chsler B. (2000). Effect of foraging material and food form on feather pecking in laying hens. Brit. Poultry Sci., 41: 16-21.

Anders on K.E., D a vis G.S., J e n k in s P.K., C a r roll A.S. (2004). Effects of bird age, density, and molt on behavioral profiles of two commercial layer strains in cages. Poultry Sci., 83: 15-23.

Anderson K.E., Jones D.R., Davis G.S., Jenkins P.K. (2007). Effects of genetic selection on behavioral profiles of Single Comb White Leghorn hens through two production cycles. Poultry Sci., 86: 1814-1820.

Calik J. (2009). Characteristics productive traits in laying hens included in the genetic resources conservation programme in Poland (in Polish). Zesz. Nauk. PTIE i PTG, Oddz. Rzeszów, 11: 21-26.

Cheng H.W., Mu ir W.M. (2004). Chronic social stress differentially regulates neuroendocrine responses in laying hens: II. Genetic basis of adrenal responses under three different social conditions. Psychoneuroendocrinology, 29: 961-971.

E1-1 e they H., Jungi T.W., Huber-Ei cher B. (2001). Effects of feeding corticosterone and housing conditions on feather pecking in laying hens (Gallus gallus domesticus). Physiol. Behav., 73: 243-251.

Fra is s e F., C o c kr e m J.F. (2006). Corticosterone and fear behavior in white and brown caged laying hens. Brit. Poultry Sci., 47: 110-119.

H e $\mathrm{t} l$ a nd H., S v i hu s B. (2007). Inclusion of dust bathing materials affects nutrient digestion and gut physiology of layers. J. Appl. Poultry Res., 16: 22-26.

H o c k ing P.M., C ha nn ing C.E., W a d d ing to n D., J o n e s R.B. (2001). Age-related changes in fear, sociality and pecking behaviours in two strains of laying hen. Brit. Poultry Sci., 42: 414 423. 
Kle in T., Zeltner E., H u ber-Eicher B. (2000). Are genetic differences in foraging behaviour of laying hen chicks paralleled by hybrid-specific differences in feather pecking? Appl. Anim. Behav. Sci., 70: 143-155.

L a y D.C. Jr., F ulto n R., He ster P., Karcher D., K j a er J., Mench J., Mullen s B., New berry R., Nicol C., O'S ullivan N., Porter R. (2011). Hen welfare in different housing systems. Poultry Sci., 90: 278-294.

L e e Y.P., Ch e n T.L. (2007). Daytime behavioural patterns of slow-growing chickens in deep-litter pens with perches. Brit. Poultry Sci., 48: 113-120.

M a h b o u b H.D.H., M ül1 e r J., B o r e 11 E. (2004). Outdoor use, tonic immobility, heterophil/lymphocyte ratio and feather condition in free-range laying hens of different genotype. Brit. Poultry Sci., 45: 738-744.

Nicol C., Lindberg A., Phillips A., Pope S., Wilkins L., Green L. (2001). Influences of prior exposure to wood shavings on feather pecking, dustbathing and foraging in adult laying hens. Appl. Anim. Behav. Sci., 73: 141-155.

Niels en B.L., Thom sen M.G., S or en sen P., Young J.F. (2003). Feed and strain effects on the use of outdoor areas by broilers. Brit. Poultry Sci., 44: 161-169.

$\mathrm{S}$ c o t t T.A., S ilve r s i d e s F.G. (2000). The effect of storage and strain of hen on egg quality. Poultry Sci., 79: $1725-1729$.

Silverside s F.G., K orver D.R., B u d g e 11 K.L. (2006). Effect of strain of layer and age at photostimulation on egg production, egg quality, and bone strength. Poultry Sci., 85: 1136-1144.

Singh R., Cheng K.M., Silversides F.G. (2009). Production performance and egg quality of four strains of laying hens kept in conventional cages and floor pens. Poultry Sci., 88: 256-264.

T a u s o n R. (2002). Furnished cages and aviaries: production and health. World. Poultry Sci. J., 58: 49-63.

Uitdehaag K.A., Komen H., Rodenburg T.B., Kemp B., van Arendonk J. (2008). The novel object test as predictor of feather damage in cage-housed Rhode Island Red and White Leghorn laying hens. Appl. Anim. Behav. Sci., 109: 292-305.

Uitdehagg K.A., Rodenburg T.B., Bolhuis E.J., Decuypere E., Komen H. (2009). Mixed housing of different genetic lines of laying hens negatively affects feather pecking and fear related behaviour. Appl. Anim. Behav. Sci., 116: 58-66.

V ä is än en J., Håk a n s s o n J., J e n s en P. (2005). Social interactions in Red Junglefowl (Gallus gallus) and White Leghorn layers in stable groups and after re-grouping. Brit. Poultry Sci., 46: $156-168$.

Wirén A., G un nar s s o n U., A nder s s o n L., Je n s e n P. (2009). Domestication-related genetic effects on social behavior in chickens - Effects of genotype at a major growth quantitative trait locus. Poultry Sci., 88: 1162-1166.

Accepted for printing 12 IX 2011

\section{EWA SOSNÓWKA-CZAJKA, EUGENIUSZ HERBUT, IWONA SKOMORUCHA, RENATA MUCHACKA}

\section{Poziom dobrostanu kur nieśnych ras zachowawczych i zestawów towarowych w systemie ściołowym}

\section{STRESZCZENIE}

Celem prowadzonych badań było określenie różnic w poziomie dobrostanu kur ras zachowawczych, takich jak Żółtonóżka kuropatwiana, Sussex, Leghorn, a także mieszańców towarowych ISA Brown, Lohmann Brown oraz Hy-Line, utrzymywanych w systemie ściołowym bezwybiegowym.

Doświadczenie przeprowadzono na 180 kurach trzech ras zachowawczych: Żółtonóżka kuropatwiana, Sussex, Leghorn oraz 180 kurach nieśnych zestawów towarowych: Hy-Line, ISA Brown oraz 
Lohmann. Nioski utrzymywano w systemie ściołowym bezwybiegowym. W trakcie doświadczenia zbierano dane produkcyjne (do 38. dnia życia kur) oraz przeprowadzono 24-godzinny monitoring zachowania się ptaków w 18., 20., 32. i 38. tygodniu życia.

Stwierdzono, że spośród trzech badanych zestawów towarowych kur nieśnych, utrzymywanych w systemie ściołowym bezwybiegowym, najniższym poziomem dobrostanu cechowały się ptaki zestawu ISA Brown, natomiast ptaki zestawu Hy-Line oraz Lohmann charakteryzowały się porównywalnym poziomem dobrostanu, wyższym w stosunku do niosek ISA Brown. Uzyskane wyniki wskazują również, że kury rasy Sussex odchowywane w systemie ściołowym zamkniętym charakteryzowały się wyższym poziomem dobrostanu w porównaniu do niosek rasy Żótłonóżka kuropatwiana i Leghorn. Porównując wyniki produkcyjne oraz behawior kur ras zachowawczych z wynikami kur zestawów towarowych można powiedzieć, że upadki oraz zwiększony poziom agresywności kur ras zachowawczych, utrzymywanych w systemie ściołowym zamkniętym, świadczą prawdopodobnie o niższym poziomie dobrostanu tych ptaków w porównaniu do poziomu dobrostanu niosek zestawów towarowych. 